Цирфба Ю. А., кандидат політичних наук, асистент кафьедри міжнародного регіонознавства Інституту міжнародних відносин Київського національного університету ілені Тараса Шевченка

\title{
СТАНОВЛЕННЯ ЗОВНІШНЬОПОЛІТИЧНОЇ ІДЕНТИЧНОСТІ ДЕРЖАВИ В КОНТЕКСТІ ФОРМУВАННЯ СУСПІЛЬНОЇ САМОСВІДОМОСТІ
}

\begin{abstract}
Анотація. Досліджено специфіку процесу вибудовування зовнішньополітичної ідентичності держави в контексті формування суспільної самосвідомості, з урахуванням етнонаціональної, культурної та соціально-психологічної характеристик останньої. Визначено, що зовнішньополітична ідентифікація $є$ істотним елементом суспільної самосвідомості, адже виділяється соціально-психологічний процес ототожнення індивіда 3 державою, на території якої він проживає, а такий взаємозв'язок передбачає становлення індивіда як суб'єкта, котрий усвідомлює себе представником тієї чи іншої спільноти.
\end{abstract}

Зовнішньополітична ідентичність повинна розмежовуватися 3 феноменом ідентичності національної, котра має розглядатися як один зі складників колективної ідентичності соціуму. Однак етнічна група чи нація може бути ідентифікована тільки в тому разі, якщо ії відмінні риси (мова, культура, расові характеристики) починають набувати соціального сенсу. Усвідомлення приналежності до певного етносу чи народу є однією з найбільш константних характеристик самосвідомості людини. Оскільки орієнтація на майбутнє в самоідентифікації індивіда має релігійний чи політичний сенс, індивід здатен пріоритезувати загальносуспільну ідентичність над етнічною через необхідність власного розвитку, що може напряму застосовуватися державою в процесі імплементації відповідної етнонаціональної політики єднання соціуму й, відповідно, виробленні підгрунтя для конструювання власної зовнішньополітичної ідентичності.

Механізми, за допомогою яких формується етнонаціональна ідентичність, мають психологічну природу. Однак самовизначення індивідів по відношенню до населення певної держави $є$ внутрішнім відображенням і суб'єктивною трансформацією зовнішніх щодо свідомості чинників, які в сукупності визначають процес формування феномену колективної ідентичності соціуму. Кожен індивід у процесі свого розвитку зазнає двовимірної детермінації - об'єктно-культурної та культурно-психологічної. Перша лінія детермінації пов'язана 3 конкретними умовами життєдіяльності, формами і типами культури, об'єктивними способами освоєння реальності. Друга лінія детермінації грунтується на елементах національної свідомості й історичній пам'яті. Історичний час будь-якого етносу чи нації осмислюється людьми, тобто проходить через їхню свідомість.

Таким чином, колективна ідентифікація соціуму має розглядатися не тільки в іiї філософсько-антропологічному аспекті, тобто як соціокультурний процес усвідомлення індивідом приналежності до певного суспільства та його культури, а й у контексті етнопсихологічного процесу кон- струювання самосвідомості етнонаціональних груп, котрі формують це суспільство.

У межах постмодерних держав формується новий тип самосвідомості соціумів, що вбирає ціннісні погляди, почуття, переживання й традиції етносів і націй, проте орієнтується на нову суспільну єдність. Держава, забезпечуючи конструювання такої самосвідомості, перетворює власне населення на активного суб'єкта історичного процесу, формуючи таким чином єдине для всіх його представників почуття соціальної ідентичності. Остання створює безпосередній базис для конструювання зовнішньополітичної ідентичності державного актора, яка за своєю природою є соціально-політичним феноменом.

Ключові слова: зовнішньополітична ідентичність, держава, соціум, самосвідомість, культура, національна ідентичність.

Постановка проблеми. Розвиток постмодерних держав напряму пов'язаний із виробленням нових стратегій і механізмів діяльності на світовій арені, адже міжнародні відносини нині все інтенсивніше втрачають характеристики, виведені апологетами позитивістських і постпозитивістських досліджень. Зовнішня політика, що продукується державними акторами, наразі не тільки спрямована на реалізацію їхніх національних інтересів, а й відображає рівні взаємодії державного апарату й соціуму, оскільки держава насамперед може трактуватися як продукт розвитку суспільства, котре послуговується власною колективною ідентичністю. Процес ідентифікації соціуму створює безпосередній базис для формування зовнішньополітичної ідентичності держави, яка конструюється в нерозривному взаємозв'язку з суспільними змінами. Отже, важливою є актуалізація соціально-психологічного моменту у розвитку держави, адже зовнішньополітичні відносини також є особливим різновидом гуманітарних, людських взаємин, котрі не можна зводити тільки до економічних чи політичних категорій.

Зовнішньополітична ідентифікація, таким чином, є істотним елементом суспільної самосвідомості, адже, по-перше, можна виділити соціально-психологічний процес ототожнення індивіда 3 державою, на території якої він проживає, з об'єктивних і суб'єктивних причин, а по-друге, такий взаємозв'язок виступає як особлива форма соціалізації особистості, що передбачає становлення індивіда як суб'єкта, котрий усвідомлює себе представником тієї чи іншої спільноти.

Аналіз останніх досліджень і публікацій. Проблематика самоідентифікації індивіда й визначення його приналежності 
до певної спільноти доволі широко розглядається в рамках різних наук гуманітарного спрямування, що трактують феномен соціальної ідентичності. Зокрема, ці питання детально розкриваються в дослідженнях таких учених, як Е. Аллард i К. Старк [5], А. Бикова [9], О.О. Бороноєв і В.М. Павленко [7], Г. Гачев [10], Р. Райан та Е. Дечі [8], С. Спенсер [4], Дж. Трім [2], С. Хантінгтон [3], К. Хюбнер [1] тощо. Однак ці дослідження майже не торкаються соціально-державних зв'язків і таким чином не розглядають суспільну самосвідомість як один із чинників становлення колективної ідентичності соціуму, котра своєю чергою може стати підгрунтям для конструювання зовнішньополітичної ідентичності держави.

Тому мета статті полягає в необхідності визначення специфіки процесу вибудовування зовнішньополітичної ідентичності держави в контексті формування суспільної самосвідомості, 3 урахуванням етнонаціональної, культурної та соціально-психологічної характеристик останньої.

Виклад основного матеріалу дослідження. Представники соціології міжнародних відносин часто задають питання: в чому полягає ідентифікація людини з суспільством держави, в якому вона розвивається, та якому внутрішньому досвіду вона відповідає? 3 цієї точки зору зовнішньополітична ідентичність держави отримує інший зміст, аніж під час дослідження суспільства як зовнішнього об'єкта. Наприклад, вироблення відповідних дослідницьких підходів і пов'язаного з ними внутрішнього досвіду людини К. Хюбнер називає феноменологією національної ідентифікації. Він зазначає, що «ідентифікація з певною нацією не є актом волі або огульного рішення. Це доля. Людина зі своєю рідною мовою, дитинством і юністю, які накладають на неї суттєвий відбиток, самим фактом свого народження належить до своєї нації, і байдуже, чи йдеться про нації мононаціональної або багатонаціональної держави, або ж взагалі про культурні нації» [1, с. 360-361]. Ї̈і «доленосна» ідентифікація виявляється багатошаровою. Навіть у випадках зміни національної приналежності «доля» зв'язку людини зі своїм походженням залишається непорушною, і нова ідентифікація відчувається як зв'язок, породжений долею. Ця внутрішня і глибока прихильність до нації і Батьківщини нерідко залишається неусвідомленою. Але національна свідомість виявляється завжди, нехай і в латентній формі, тому не може бути викоріненою, а реакція на іiі витіснення або навіть придушення може призвести до небезпечного суспільного вибуху [1, с. 361].

К. Хюбнер зазначає, що «для національно релевантних груп може бути притаманною навіть ірраціональна, сліпа, афективна поведінка, оскільки динаміка безлічі національних систем не складає їх в готову тотальність і ніколи не завершується логічно» [1, с. 362]. Тобто можемо припустити, що дослідник розглядає соціум як сукупність національних систем, котрі не існують як тотальність. Отже, можна віднайти регулятивну ідею функціонування національних груп у рамках єдиного суспільного утворення, котре має визначатися як населення держави. При цьому окремі нації, як і особистості, продовжують жити зі своїми протиріччями, а боротьба з національними протиріччями виявляється боротьбою за колективну ідентичність соціуму, котра може бути введена до правового поля держави завдяки реалізації відповідної політики ідентифікації.

Звичайно, категорія зовнішньополітичної ідентичності все більше привертає увагу дослідників через іiї евристичну зна- чимість і практичну важливість. Тому, будучи соціально-політичним феноменом, цей конструкт повинен розмежовуватися 3 феноменом ідентичності національної, котра, по суті, нині має розглядатися як один зі складників колективної ідентичності соціуму. Так, наприклад, Рада 3 культурного співробітництва, яка діє при Раді Європи, досліджуючи проблему національної ідентичності з позицій чинників, що впливають на їі формування, дійшла висновку, що цей феномен може розглядатися 3 трьох точок зору:

1) функціоналістської, адже вона виконує зовнішні і внутрішні функції: з одного боку, вона дає індивіду можливість відрізняти себе від «Інших» («Ми» від «Вони»), з іншого визначає його соціальний простір щодо певної території, економіки, політики, історичних і духовних точок відліку;

2) релятивістської, оскільки ідентичність перебуває в процесі постійних змін;

3) плюралістської, адже кожному індивіду притаманна низка ідентичностей: національна ідентичність, яка визначається мовою і територією, не є єдиною характеристикою цього суб'єкта [2, с. 18-22].

Дослідники зазвичай виділяють два типи національної ідентичності, причому дають їм різні назви: цивільна та етнічна, або політична і культурна, або революційна і трайбалістська, або ліберальна й інтеграційна, або раціонально-асоціативна й органічно-містична, або цивільно-територіальна й етнічно-генеалогічна, або, що найчастіше, патріотизм і націоналізм [3, с. 62]. У кожній парі перший тип національної ідентичності набуває позитивних якостей, а другому, навпаки, найчастіше приписуються негативні характеристики. Тобто громадянський націоналізм має на увазі існування відкритого соціуму, заснованого на суспільному договорі, до якого можуть приєднатися і тим самим стати громадянами держави, в межах якої це суспільство розвивається, люди будь-якої раси чи національності. Етнічний націоналізм за контрастом є обмежувальним: «членство» в нації надається лише тим особам, які мають певний набір базових етнічних і культурних ознак.

У такому контексті потрібно зауважити, що вплив етнічної культури на людину, на формування особистості не $є$ прямолінійним. Це пояснюється тим, що проблема взаємин особистості й етносу по-різному розглядається в рамках наук, які вивчають різнорідні сфери прояву національних рис. Можна говорити про соціально-філософський, або загальносоціологічний, підхід, представники котрого розглядають людину як суб'єкт національних відносин із точки зору існування і зміни історичних форм соціально-етнічних спільнот людей. Етнічна приналежність досліджується при цьому як один зі зрізів зв'язку особистості з суспільством. У межах етносоціологічного підходу етнічна визначеність особистості трактується як відображення в іiі структурі соціальних особливостей певної етнічної спільноти $[4$, с. 8-9].

Етнічна група може бути ідентифікована тільки в тому разі, якщо іï відмінні риси (мова, культура, расові характеристики) починають набувати соціального сенсу: з одного боку, ця група має ідентифікуватися як етнічно особлива 3зовні; з іншого боку, сама група повинна усвідомити свою специфічність і особливість. Позитивне значення ідентифікації етнічної групи - це збереження традицій, культури, вкоріненої глибоко в соціальних структурах історичної спадщини. У зв'язку з цим, Е. Аллард і К. Старк визначили чотири обов'язкові критерії 
детермінування етнічної групи. Отже, для зарахування індивіда до етнічної групи має виділятися одна (або кілька) з наведених нижче характеристик його особистості:

1) самовизначення, зарахування себе до етнічної групи;

2) наявність родинних зв'язків, спільних коренів серед членів будь-якої групи населення;

3) специфічні культурні риси, володіння спільною мовою;

4) наявність соціальної організації для здійснення внутрішніх контактів і взаємодії з оточуючими [5, с. 38-41].

Виходить, що центральним фактором приналежності до етнічної групи є власне бажання індивіда належати до неї, тобто ідентифікувати себе як члена групи. Зовнішня ідентифікація цієї особи грунтується зазвичай на зовнішніх прикметах, таких як знання мови або зовнішній вигляд. Походження друга умова приналежності до групи. Члени етнічної групи входять до неї на основі загальної національності, що передається з покоління в покоління.

Усвідомлення приналежності до певного етносу, народу $€$ чи не найбільш константною характеристикою самосвідомості людини. Воно не залежить від зміни соціальних ролей, соціального статусу, видів діяльності, місця проживання тощо. Людина відчуває себе представником певного народу, ототожнює, ідентифікує себе з ним. Однак маємо відзначити, що самоідентифікація особистості може мати різні форми, які відрізняються своєю спрямованістю і відображають в індивідуальній свідомості основні градації громадської стратифікації. У такому ключі самоідентифікація індивіда пов'язана 3 усвідомленням себе громадянином конкретної держави, членом певної професійної групи, класу тощо. Таким чином, орієнтація на минуле формує його етнічну ідентичність, що базується на спільності походження, вірувань, традицій, цінностей, відчутті історичної наступності. Орієнтація на майбутнє в самоідентифікації індивіда має зазвичай релігійний чи політичний сенс, зумовлений досягненням будь-яких універсально значущих цілей [6, с. 230]. Отже, індивід здатен пріоритезувати загальносуспільну ідентичність над етнічною через необхідність власного розвитку, що може напряму застосовуватися державою в процесі імплементації відповідної етнонаціональної політики єднання соціуму й, відповідно, виробленні підгрунтя для конструювання власної зовнішньополітичної ідентичності.

Механізми, за допомогою яких формується етнонаціональна ідентичність, безсумнівно, мають психологічну природу. Однак самовизначення індивідів по відношенню до населення певної держави є внутрішнім відображенням і суб'єктивною трансформацією зовнішніх щодо свідомості чинників, які в сукупності визначають процес формування феномену колективної ідентичності соціуму. Значення таких чинників у підтриманні цієї ідентичності може бути різним. Так, територія як засіб збереження групового зв'язку може бути вирішальним фактором підтримання колективної ідентичності або взагалі не мати ніякого значення.

Оскільки етнічні особливості психіки й поведінки особистості, а також соціально-психологічні форми їі участі в міжетнічних взаємодіях визначають ті властивості людини, яких вона набуває в процесі соціалізації, саме етнопсихологічна проблематика знаходиться в центрі уваги під час вивчення проблем особистості, в тому числі іiі ідентичнісної варіативності. В рамках цієї проблеми важливим видається звернення до етнічної психології, яка дозволяє простежити тенденцію формування особистості, іiі поведінкові та ціннісні орієнтації. Так, наприклад, О. Бороноєв і В. Павленко розглядають етнічну психологію як складну багаторівневу систему. Перший рівень складають почуття, настрої, переживання, емоційні стани свідомості людини; другий - елементи «психічного складу», пов'язані 3 наступністю, що виступають як феномен масового, народного досвіду діяльності, спілкування всередині і зовні етносу, а також впливу природно-екологічних умов існування. На цьому рівні виявляється національний характер - специфічна поведінка, національні традиції, звичаї, звички, які лежать в основі установок, ціннісних орієнтацій індивіда. В сукупності всі ці елементи і категорії складають єдину систему [7, с. 7-8].

Таким чином, національна самосвідомість включає ідеали, погляди, уявлення, пов'язані 3 найважливішими сторонами життя, і спілкування спільнот як соціально-етнічних організмів. Тому ці характеристики виступають у ролі сторони і форми духовно-психологічного, морального, естетико-культурного образу національної спільноти. Незважаючи на такий доволі складний синтез різних тенденцій, національна культура становить самостійне явище, самоцінне і неповторне саме по собі, що визначає іiі функції, зокрема під час формування «національного типу» особистості. Вона має на людину подвійний вплив - внутрішній і зовнішній. Вона визначає ті цінності, інтереси, етичні норми, емоційні стани, які представляють сутнісні мотиви діяльності людини. Нею ж зумовлюється своєрідність зовнішнього прояву цих мотивів.

Нерозуміння в теорії й ігнорування на практиці значення етнічної структури призводить до нівелювання національних інтересів, етнічних цінностей, традицій, навичок, котрі становлять основу процесу соціалізації особистості, формування iii особистісної визначеності. Справа в тому, що різні етнокультурні системи зумовлюють різнорідність характерів формування в них особистісної визначеності. Залежно від етносоціальної структури, будови, конструювання та сприйняття соціальної організації можна говорити принаймні про два іiі типи: самовизначення через ієрархію, з властивою для нього підвищеною чутливістю до ієрархічної будови соціального простору і визначення місця індивіда в цій ієрархії; і самовизначення через діяльність, якому притаманна відносна байдужість до соціальної ієрархії, але значна чутливість до особистісного, індивідуального вкладу в той чи інший вид діяльності незалежно від приналежності особи або ії позиції у групі [8, с. 71-72]. Зазначені типи особистісного самовизначення людини, закріплені в стереотипах поведінки і сприйняття, відтворюються і транслюються за допомогою зв'язків між поколіннями, виступаючи важливим етноконсолідуючим чинником.

Кожен індивід у процесі свого розвитку зазнає двовимірної детермінації: об'єктно-культурної та культурно-психологічної. Об'єктно-культурну детермінацію людини визначають матеріально-речове середовище, природно-ландшафтні умови, об'єктивізовані елементи національної культури тощо. Друга лінія детермінації грунтується на елементах національної свідомості й історичній пам'яті. У цьому контексті слід підкреслити роль історичного знання і досвіду як важливої частини соціальної пам'яті, нормативно-спадкоємних елементів (традицій, звичаїв тощо) національної свідомості, елементів національної самосвідомості, які включають ідеали розвитку людини, форм емоційно-чуттєвого сприйняття навколишнього світу, цінностей і традицій спілкування [9, с. 278]. 
Перша лінія детермінації пов'язана 3 конкретними умовами життєдіяльності, формами і типами культури, об'єктивними способами освоєння реальності. Так, географічні умови, оточення впливають на характер поведінки, сприйняття, види діяльності індивідів. Проте очевидно, що, наприклад, мова має суттєвий вплив на процес становлення особистості, привносячи до іiї свідомості, мислення свою специфіку. 3 іншого боку, в мові виражаються психологічні особливості індивідуальності людини. Таким чином, колективна ідентифікація соціуму має розглядатися не тільки в її філософсько-антропологічному аспекті, тобто як соціокультурний процес усвідомлення індивідом приналежності до певного суспільства та його культури, а й у контексті етнопсихологічного процесу конструювання самосвідомості етнонаціональних груп, котрі формують це суспільство.

Історичний час будь-якого етносу чи нації осмислюється людьми, тобто проходить через їхню свідомість. Адже об'єктивна картина світу визначається під невидимим впливом первинно заданих, апріорних правил мислення, відмінних від правил мислення людей, котрі користуються іншою мовою та мають відмінну історію. Те, що таким невидимим чином впливає на сприйняття, можна, користуючись термінологією Г. Гачева, назвати «національним образом світу». Під ним мається на увазі «національний погляд на світ», «гносеологія», національна, художня «логіка», склад мислення, «сітка координат», за допомогою якої певний народ уловлює світ і, відповідно, вибудовує перед очима свій «космос» [10, с. 85].

Таким чином, без вироблення національного образу світу, незважаючи на наявність об'єктивних чинників, національна спільнота аморфна, іiї не можна визнати повноцінним суб'єктом історичного процесу. Але їі духовно-психологічна єдність за сучасних умов спирається на територіально-економічний та історико-культурний компоненти. А зовнішні символи єдності (територія, господарство, історія) повною мірою розкривають внутрішній, екзистенційний сенс буття населення, перетворюючись на об' єктивні сторони життя націй, що виступають його формотворчими одиницями. Таким чином, у межах постмодерних держав формується новий тип самосвідомості соціумів, що воирає ціннісні погляди, почуття, переживання й традиції етносів і націй, проте орієнтується на нову суспільну єдність. Держава, забезпечуючи формування такої самосвідомості, перетворює власне населення на активного суб'єкта історичного процесу. Через свідомість, ціннісні орієнтації, традиції, що набувають загального характеру, соціальна сутність групи виявляється в реальному вимірі. Адже кожна людина соціалізується, усвідомлюючи свою приналежність, свою спорідненість із суспільним цілим. Тому державний механізм, долучаючись до цього процесу, може сприяти об'єднанню всіх суспільних груп у певну цілісність, формуючи таким чином єдине для них почуття соціальної ідентичності. Остання є безпосереднім базисом для конструювання зовнішньополітичної ідентичності державного актора, яка за своєю природою є соціально-політичним феноменом.

Висновки 3 дослідження і перспективи подальших пошуків у цьому науковому напрямі. Отже, зовнішньополітична ідентичність має розглядатися в двох вимірах: у філософсько-антропологічному - як індивідуальний процес усвідомлення приналежності індивіда до населення певної держави та його культури; і в соціально-історичному - як осмислення необхідності визначення долі власної держави з боку людини з метою обрання історичного шляху іiі розвитку i, відповідно, iii зовнішньополітичної ідентифікації.

Загалом системна розробка поняття зовнішньополітичної ідентичності здатна розширити політологічні уявлення про процес діяльності держави на міжнародній арені. Адже історію кожної країни творять люди, які в своїх діях (у тому числі, й зовнішньополітичних) керуються, серед іншого, й уявленнями про самих себе, про те, до чого вони покликані, чому служать, що повинні представляти, над чим працювати й чого домагатися. Відповідно, держава може змінювати власну зовнішньополітичну ідентичність, оскільки соціум постійно прагне до відповідності між власним ідеальним і фактичним станом. Розвиваючись у такому полі соціальної напруги, зовнішньополітична ідентичність конструюється, вбираючи задані вектори розвитку соціуму й держави. Однак остання має здатність контролювати цей процес зсередини, налагоджуючи діалог із соціумом та впроваджуючи орієнтовану на встановлення нового типу суспільної самосвідомості етнонаціональну політику.

\section{תimepamypa:}

1. Хюбнер К. Нация: от забвения к возрождению. Москва, $2001.400 \mathrm{c}$.

2. Trim J. L. M. Modern Languages in the Council of Europe 1954-1997. International cooperation in support of lifelong language learning for effective communication, mutual cultural enrichment and democratic citizenship in Europe. Strasbourg, 1997. 60 p. URL: https://rm.coe.int/ modern-languages-in-the-council-of-europe-1954-1997-internationalсо-о/1680886еае (дата звернення: 26.11.2019).

3. Хантингтон С. Кто мы? Вызовы американской национальной идентичности. Москва, 2004. 635 с.

4. Spencer S. Race and Ethnicity: Culture, Identity and Representation. London, 2006. $273 \mathrm{p}$.

5. Allardt E., Starck Ch. Sociology. Helsinki, 1981.296 p.

6. Hüsamettin İ., Feyzullah Ü. The Construction of National Identity in Modern Times: Theoretical Perspective. International Journal of Humanities and Social Science. 2013. Vol. 3, № 11. P. 223-232.

7. Бороноев А.О., Павленко В.Н. Этническая психология. Санкт-Петербург, 1994. $166 \mathrm{c}$.

8. Ryan R.M., Deci E.L. Self-Determination Theory and the Facilitation of Intrinsic Motivation, Social Development, and Well-Being. American Psychologist. 2000. Vol. 55, № 1. P. 68-78.

9. Bykova A.V. Analysis of Socio-Cultural and Socio-Psychological Nature of the Educational Process. Social and Behavioral Sciences. 2013. № 86. Р. 277-282.

10. Гачев Г.Д. Национальные образы мира. Москва, 1998. 429 с.

Tsyrfa I. Foreign policy identity of the state in the context of formation of social self-consciousness

Summary. The peculiarities of construction of the foreign policy identity of the state in the context of formation of social self-consciousness, taking into account its ethnonational, cultural and socio-psychological features, are explored. The foreign policy identification is determined to be an essential element of social self-consciousness, as it presupposes the socio-psychological process of identification of an individual with the state where they resides, and such a relationship implies the formation of the individual as a subject who recognizes themselves as a representative of a particular community.

Foreign policy identity should be distinguished from the phenomenon of national identity which is considered as 
one of the components of the collective identity of the society. However, an ethnic group or a nation can only be identified if its distinctive features (language, culture, racial features) make social sense. Awareness of belonging to a particular ethnic group or people is one of the most constant characteristics of a personal self-consciousness. Since orientation for the future has religious or political meaning in the process of selfidentification of the individual, the latter is able to prioritize social identity over the ethnic one because of the need for their own development: this can directly be applied by the state while implementing the appropriate ethnonational policy to unite the society and, therefore, to form the basis for its own foreign policy identity.

The mechanisms to form the ethnonational identity have psychological nature. However, self-determination of individuals as a part of the population of a certain state is an internal reflection and subjective transformation of the external factors to influence consciousness which collectively determine the formation of the phenomenon of collective identity of the society. In the course of their development, every individual is subjected to twodimensional determination: object and cultural and cultural and psychological. The first line of determination is related to specific conditions of life, forms and types of culture, objective ways to interpret reality. The second line of determination is based on the elements of national consciousness and historical memory. The historical time of any ethnic group or nation is conceived by people, i.e. it passes through their consciousness.

Thus, the collective identification of the society should be considered not only in its philosophical and anthropological dimension (as a social and cultural process of the individual's awareness of their belonging to a particular society and its culture), but also in the context of the ethno-psychological process to construct the self-consciousness of ethnic and national groups forming this society.

The postmodern states form a new type of social selfconsciousness which absorbs the values, feelings, experiences and traditions of ethnic groups and nations but is oriented towards a new social unity. By constructing such selfconsciousness, the state transforms its own population into an active subject of the historical process and, therefore, forms a sense of social identity between the people. This identity establishes a basis for constructing the foreign policy identity of the state actor, since it is a social and political phenomenon by its nature.

Key words: foreign policy identity, state, society, selfconsciousness, culture, national identity. 